DOI 10.14746/ssp.2018.3.7

Paweł BŁASZCZYK

Poznań University of Economics and Business

Łukasz FoJuTowsKi

Collegium Da Vinci

\title{
Convergence of price dynamics assessed in view of Poland's accession to the euro area focusing on deflation
}

\begin{abstract}
The primary aim of this study was to assess the degree of Poland's convergence in terms of price stability, both at the stage of the country's candidacy to the euro area and in relation to the euro convergence criteria (the so-called Maastricht criteria), and in the broader context of the ECB's unified monetary policy. The time frame for this study covers the period of 2004-2017. The starting point marks Poland's accession to the EU, which is a pre-requisite for application to access the euro area. The closing time was chosen due to the availability of data, mainly from the Eurostat database. This was studied in view of the critical analysis of methodology and the method used to establish the Maastricht criterion for the dynamics of the general price level. The methodology of determining the inflation criterion is flawed and not matched to today's economic conditions, including the definition of price stability applied in the practice of central banking, as well as in the context of the phenomenon of deflation commonly occurring in the last decade. As a consequence, the value of the criterion for a candidate country may turn out to be very low, and may unjustifiably increase the costs of accession to the euro area, also in the long-term perspective. Such a problem should be taken into account in the discussion on Poland's accession to the euro area, which is usually of a political, as well as social and economic nature. This economic aspect, however, should be key in practice.
\end{abstract}

Key words: deflation, economic integration, euro area, monetary policy, price stability

\section{Introduction}

$\mathbf{E}$ uropean integration processes lasting many decades now have been strongly connected with the process of convergence, understood as the process of economies becoming increasingly similar, which leads to their convergence. On the one hand, convergence is a pre-condition for 
integration, while on the other hand it is its objective, which is to contribute to the socio-economic growth and development of united Europe. When we consider the European Union (EU) and the euro area (EA) as a certain stage in the overall integration process (Molle, 2000, part I ff.), which may be termed as an incomplete economic and monetary union (De Grauwe, 2003, pp. 107-140; Zwierzchlewski, 2015, Chapter 1), we need to stress that certain conditions need to be met to participate, such as those related to economic convergence, both in terms of membership of the EU and next also of the EA. In turn, accession to such associations may promote convergence, as indicated e.g. by the structure and scale of the EU budget. Fiscal policy in Europe is primarily executed at the national level (both central and local governments), while the EU budget is mainly to ensure redistribution in order to enhance socio-economic cohesion within more specific areas (see EU budget structure). However, its excessive growth and incorporation of a wider range of fiscal functions outside the area of convergence are considered disadvantageous, as evidenced by the limit for its volume established at $1.24 \%$ of the GDP of member countries. ${ }^{1}$

Also in the monetary (currency) aspect, convergence is inseparably associated with European integration. In this sense, it refers first of all to the Maastricht criteria as pre-conditions for accession to the euro area. However, these should not be considered solely as boundary conditions to be met in order to access the European Monetary Union, but rather as a completion and verification of the conclusion for the convergence process in relation to the applicant country. This study is focused on the criterion related to price stability and more broadly speaking - to the entire convergence process in this area in view of accession and membership in the Monetary Union (compare Ochryniuk, Rogut, 2010). This is connected with serious problems, not only for the euro area candidate country which has to meet the requirement not only before, but also after accession; a problem lies also in the methodology of establishing the criterion itself. The above-mentioned problems discussed within this study have a significant impact on the balance of costs and benefits connected with accession to the zone of the common European currency (De Grauwe, 2003, Chapters 1-4). Divergence in the dynamics of the general price level not only hinders accession to the euro area and makes it more costly, but also leads to incompatibility with the EU's unified monetary policy of

\footnotetext{
${ }^{1}$ For more on the EU budget and its rules see: e.g. Zombirt (2008, pp. 455-489).
} 
the European Central Bank (ECB) and generates resulting participation costs (Błaszczyk, 2016).

This is a particularly important issue from the point of view of the challenges of economic policy in Poland in the face of accession to the euro area. An economic analysis of the balance of costs and benefits should be the basis for the discussion on making the final political decision on the date of accession - a decision which, however, is not only political and economic, but also social in nature. ${ }^{2}$ Our decision-makers should consider a number of factors regarding both the pre-accession process and the conditions of belonging to the euro area, particularly in the face of the crisis situations in European economic and monetary union in the last decade (Walkowski, 2012). It should be emphasized that this article focuses mainly on economic and monetary aspects of convergence with the euro area.

In this context, the primary aim of this paper is to assess the degree of Poland's convergence in terms of price stability, both at the stage of our candidacy to the euro area and in relation to the Maastricht criteria, and in the broader context of the ECB's unified monetary policy. These aspects were studied in relation to the critical analysis of the methodology and the method used to establish the Maastricht criterion for the dynamics of the general price level. The time frame for the study covers the period of 2004-2017. The starting point marks Poland's accession to the EU, which is a pre-requisite for the application to access the euro area. The closing time point results from the availability of data, mainly in relation to the Eurostat database.

This study is composed of two basic parts. One concerns the methodology for the Maastricht inflation criterion. ${ }^{3}$ A critical analysis of it was performed, indicating its incompatibility with current economic conditions, particularly in view of the definitions of price stability applied in central banking practice, as well as the deflation phenomena observed in the last decade. The paper presents the phenomena which should be con-

${ }^{2}$ For a broad look at the balance of costs and benefits of Poland's accession to the euro area against the background of the economic convergence process see: e.g. NBP (2009), Wójcik (2008), Pronobis (2008), Szelagg (1998).

${ }^{3}$ In view of the potential inclusion of reference countries experiencing deflation in the establishment of the criterion, the term inflation criterion is incorrect. It should rather be referred to as price stability or dynamics of the general price level. However, in view of common use it was decided also to use the phrase inflation criterion in this study. 
sidered in the adaptation of the methodology, e.g. in the context of Monetary Union, to be applied in the regional variation in the dynamics of the general price level. In the following part, several variants for changes in the methodology of the Maastricht inflation criterion are presented, and then in this context nominal convergence in Poland is assessed.

\section{Price stability and the Maastricht inflation criterion}

The Maastricht inflation criterion is one of the five primary nominal pre-conditions for accession to the EA. The other criteria concern longterm interest rates and government debt, as well as exchange rates. The idea underlying these criteria is to achieve and maintain a specific degree of convergence which will determine the balance of costs and benefits of EA membership. Economic convergence of the countries promotes the increased effectiveness and efficiency of the ECB's unified monetary policy. Countries which deviate from the EA average may incur losses resulting from the incompatibility of the unified policy with domestic economic conditions, particularly the dynamics of the general price level. This may result in one of the most often stressed threats for accession to the EA, i.e. loss of autonomy in monetary and exchange rate policies. In the case of monetary divergence, the unified ECB instruments, established based on the average parameters for EA and considering a 2\% inflation target, may be unsuitable for countries unable to meet the fixed parameters. For example, in countries with the lowest inflation rates, or even deflation, the EU monetary policy would become too restrictive (due to the high real rate), having a negative effect on employment rates and domestic product, while in countries with higher inflation rates it would be too expansive (due to the low real rate), promoting further increases in inflation, instead of stabilizing it at the level of the EA target. As a result, on the one hand the situation on the labor market would deteriorate, while on the other hand inflation trends would accelerate, e.g. in relation to the expected inflation rate. In contrast, if convergence is properly executed, taking into consideration long-term forecasts, and not only in view of meeting the Maastricht criteria, the above-mentioned autonomy of national policies will never be needed (or will only be needed rarely) and the unified ECB policy will prove sufficient.

The idea of the inflation criterion for convergence is thus particularly positive in the context of European integration, a process currently observed at the level of economic and monetary policies, having already covered the level of markets both for goods and services and factors of production, including e.g. the stages of the free trade zone, customs union 
or the common market (Molle, 2000). However, doubts may be raised on the one hand by the methodology used to establish this criterion ${ }^{4}$ and on the other hand - by its implementation by the candidate countries and their EA counterparts.

In relation to the concept of reaching a high level of sustainable convergence within the euro area, the Treaty stipulates that one of the conditions is "the achievement of a high degree of price stability; this will be apparent from a rate of inflation which is close to that of, at most, the three best performing Member States in terms of price stability" (Article 140 of the Treaty on the Functioning of the European Union). According to Article 1 of the Protocol on the Convergence Criteria the level of inflation in a given country within the year preceding the analysis may not exceed the inflation rates in the three EU states with the most stable price levels expressed in terms of HICP (Harmonised Index of Consumer Prices) by more than $1.5 \mathrm{pp}$. The method of identifying reference countries raises doubts. It is difficult to clearly define the term "best performing Member States in terms of price stability." Price stability can be an ambiguous concept (Błaszczyk, 2010), particularly in relation to the quantitative aspect. Apart from the other aspects of the definition of price stability, particularly disregarding its potential measurement through the price level path, and assuming the rate of change in the general price level, its target value needs to be considered (Błaszczyk, 2010).

The European Commission is not consistent in the identification of reference states, and thus in defining "the best performance in terms of price stability." Generally, countries with the lowest mean annual rate of inflation are selected. A problem appeared in the case of zero and negative dynamics of the general price level. For example, in 2004, in the Reports on Convergence the European Committee decided to eliminate Lithuania from the group of reference countries, which at that time was experiencing deflation measured using HICP. However, already in 2010, with several EU countries reporting deflation (Ireland, Portugal, Estonia, Belgium, Spain) the European Commission arbitrarily decided only to eliminate Ireland, with the highest deflation rate, from the reference state group. In the following years, when deflation was recorded worldwide, in relation to decreasing prices of raw materials on the world markets, including oil, countries with deflation were not rejected.

${ }^{4}$ An interesting collection of studies on the validity of the definition of price stability as well as the entire ECB monetary policy strategy is available from the ECB (2003). 
In such a situation, apart from the fact that the investigated criterion is relative in character and its variability may cause uncertainty regarding an EA candidate country, it may prove to be undesirably low, including values close to zero, or even hypothetically negative. We may thus question whether it is justified to meet such a 'reduced' criterion, due to the potential forcing of a considerable restriction of economic policy and related unjustified high costs. For example, a situation may arise in which a candidate country would have to reduce an inflation level which under normal conditions would be considered advantageous and optimal (e.g. $2.5 \%$ ), to values considered harmful (close, equal to or below zero), since this is indicated by the current situation in the euro area, specifically in relation to only the three countries with the lowest price dynamics. Surprisingly, the value of the criterion may be incompatible with the ECB's definition of price stability, indicating $2 \%$ inflation, while the idea behind the implementation of this criterion is to achieve convergence with the euro area and adaptation to the 'average' unified ECB policy, which determines the long-term benefits from EA membership. Why is the value of the criterion to be determined by countries with the lowest price dynamics (irrespective of the addition of $1.5 \mathrm{pp}$ to the mean price dynamics in those countries) and not, for example, those with medium dynamics, since the ECB policy refers mainly to such a parameter? Thus, it is necessary to discuss the redefinition of the price stability criterion, or at least to clearly specify the concept of countries with the greatest price stability. To do this, the notion of price stability needs to be analyzed.

It would seem that price stability is equivalent to zero inflation. However, hypothetically price stability may be defined in terms of a negative, zero or positive rate of change in the general price level. Each solution has its advantages and disadvantages; however, both empirical studies and central banking practice definitely indicate a positive inflation target. The value most commonly applied by countries using the direct inflation targeting strategy, assuming price stability as a primary objective, and specified explicitly in the form of the inflation target falls within the range of $2-3 \%$ (Błaszczyk, 2010). For example, inflation targets of the oldest central banks worldwide, i.e. Sveriges Riksbank and the Bank of England, amount to 2\%, similarly as it is for the Federal Reserve System (since 2012) and the Bank of Japan (since 2013). At present, the ECB defines price stability as inflation below $2 \%$, but close to that value, whereas for the National Bank of Poland NBP it is $2.5 \%+/-1 \mathrm{pp}$. Discussions on price stability indicate that the reference countries being best performers in terms of price stability in 
relation to the Maastricht criterion should have this specified inflation level. Taking into consideration the EU countries, and at the same time candidate or EA countries, the term "the greatest price stability" should refer to the ECB target, i.e. approx. $2 \%$ or slightly below that value, such as $1.5-2 \%$ and possibly also above, considering the symmetry of the inflation target. Thus, the candidate countries would strive to attain a target, which will later be binding within the ECB's unified monetary policy.

From the point of view of both the society and the economy, many factors indicate the advisability of establishing a positive (non-zero and non-negative) inflation target reflecting the optimal dynamics of the general price level. They include e.g.:

- downward nominal wage rigidity (Akerlof, Dickens, Perry, 1996, pp. 1-59; Akerlof, Dickens, Perry, 2000; Keynes, 2003, pp. 231-244; Kwiatkowski, 2002, p. 105; Wojtyna, 2004, p. 202; for Japan: Kimura, Ueda, 1997; for the USA: Lebow, Saks, Wilson, 2003; for Switzerland: Fehr, Goette, 2000; for Germany: Knoppik, Beissinger, 2001: for Sweden: Ekberg, 2002; for Great Britain: Nickell, Quintini, 2003, and for Italy: Devicienti, 2004);

- nominal interest rate floor (Wojtyna, 2001; IMF, 1999, p. 101; Svensson, 2000, pp. 27-28, 41);

- risk of deflation (Kumar, Baig, Decressin, Faulkner-MacDonagh, Feyzioglu, 2003; Kilian, Manganelli, 2007, pp. 561-588);

- overestimation of actual dynamics of the general price level (mainly CPI and similar measures) (Social Security Administration, 1996; Friedman, 2002, pp. 89-90, Wynne, Rodriguez-Palenzuela, 2002);

- seigniorage (Cukrowski, 2001);

- regional variation in dynamics of the general price level in the Monetary Union (Weber, Beck, 2005; Wójcik, 2008, pp. 106-142; Aldasoro, Zdarek 2009; Błaszczyk, 2014; Błaszczyk, 2016).

In order to present these aspects in terms of the identification of the inflation target we may use formula 1.

$$
\Pi^{*}=\Pi_{\mathrm{E}}+\max \left\{\Pi_{\mathrm{DNWR}}, \Pi_{\mathrm{DNIRB}}, \Pi_{\mathrm{DT}}, \Pi_{\mathrm{RVPD}} \cdots\right\}
$$

where:

$\Pi^{*}$ - value of the inflation target,

$\Pi_{E}-$ value of error for inflation measurement,

$\Pi_{\text {DNWR }}$ - inflation rate considering downward nominal wage rigidity,

$\Pi_{\text {DNIRB }}$ - inflation rate constituting downward bound against nominal interest rate floor, 
$\Pi_{\mathrm{DT}}-$ inflation rate hedging against other deflation threats, e.g. liquidity trap or deflation spiral,

$\Pi_{\mathrm{RVPD}}-$ inflation rate considering regional variation in price dynamics within the Monetary Union.

The beginning of the formula needs to include an error for the measured dynamics in the general price level, above all overestimation. Preferably, the errors should be eliminated, rather than included in the target value. Thus, the factor differs from the others indicated in the procedure, since their incorporation is, in reality, required to attain the target inflation rate. The other phenomena are substitutionary in relation to one another, i.e. the maximum inflation value resulting from each of them provides a buffer against all the others. For this reason, this value is added to the measurement error. The formula ends with an ellipsis to indicate that other factors, more or less directly associated with deflation conditions, may be included, e.g. inflation rate generated by the profits from seigniorage. In view of current monetary policy, including the independence of central banks, this argument is increasingly losing importance, particularly in relation to Monetary Union. Estimates for individual factors in this formula will differ for individual countries/ unions, and thus it is impossible to indicate a universal optimal value of inflation target.

In the case of monetary union, such as in the euro area, an additional factor will be connected with the regional diversity in the dynamics of the general price level. This results first of all from the asymmetry of shocks affecting various countries, and differences in the mechanisms of their transmission. The reasons may stem from the regulations of the product and labor markets (Moretti, 2014). In this context we should also stress the role of the Harrod-Balassa-Samuelson effect (H-B-S). It affects mainly those countries which are characterized by a relatively high growth rate in the production efficiency of exchangeable goods. This increase leads indirectly to a real, absorbable appreciation of currency, or nominal appreciation, or through a greater growth rate for domestic prices. According to the H-B-S model, this mechanism consists of a rapid growth in productivity in the exchangeable goods sector, leading to an increase in wages in that sector. This is because prices for those goods are exogenous, and are determined on the world market. Since we are dealing with perfect capital mobility between the sectors of exchangeable and non-exchangeable goods, wages in the latter sector will also increase. However, the growth rate in productivity is lower. 
The increase in wages will be reflected in the growth of prices in the non-exchangeable goods sector and as a consequence - in an increase in the general price level.

Finally, countries with a high productivity growth rate (first of all small, open emerging economies) will potentially have higher inflation in comparison to countries with a lower growth rate, but not a lower level of productivity (primarily more developed countries) (Chmielewski, 2003). Inflation resulting from the H-B-S effect may be considered 'good.' This may be termed as resulting from a reduced distance between more and less developed economies. For this reason, it is not advisable to take actions to reduce such inflation. It should be first included in the ECB inflation target, and secondly it needs to be incorporated in the methodology for the Maastricht criterion.

An empirical assessment of regional differences in the general price level dynamics in the euro area, as compared to that in the entire EU in the years of 2004-2017, is presented in Fig. 1.

The data given in the top section of Fig. 1 refer to the maximum, minimum and average price dynamics in EA countries. We can observe a considerable variation in these values at the simultaneous extensive deviations between them, which show no definite upward or downward trend. It is also evident in the bottom figure as considerable changes in the range, which for the EA falls within the range of $\langle 2.2,6.3\rangle$, while for standard deviation it is $\langle 0.63,1.25\rangle$. In view of the low values of inflation rates in the euro area countries and the ECB inflation target itself, these differences turn out to be relatively large. It should also be stressed here that the variation for the entire EU in the analyzed period is much broader than for the euro area. In this case, the range is $<2.7$, $13.1\rangle$, while standard deviation is $\langle 0.62,2.28\rangle$. Nevertheless, a positive result is connected with the increasing convergence of both measures for the EA and the EU in recent years, particularly since $2014 .^{5}$ However, regional differences in the general price level dynamics in the EA are evident, and this fact should be taken into consideration both in the methodology for the criterion of nominal convergence and the value of the ECB inflation target.

${ }^{5} \mathrm{Cf}$. research on the differences in price dynamics in the euro area with the use of an interesting, different econometric methodology. The authors come to the conclusion, which is confirmed in this article, that the analyzed differences should disappear in the future, and additionally do not undermine the legitimacy of the inflation target of the ECB (Weber, Beck, 2005). 
Fig. 1. Assessment of regional differences in the general price level dynamics in the euro area, as compared to that of the entire European Union 2004-2017

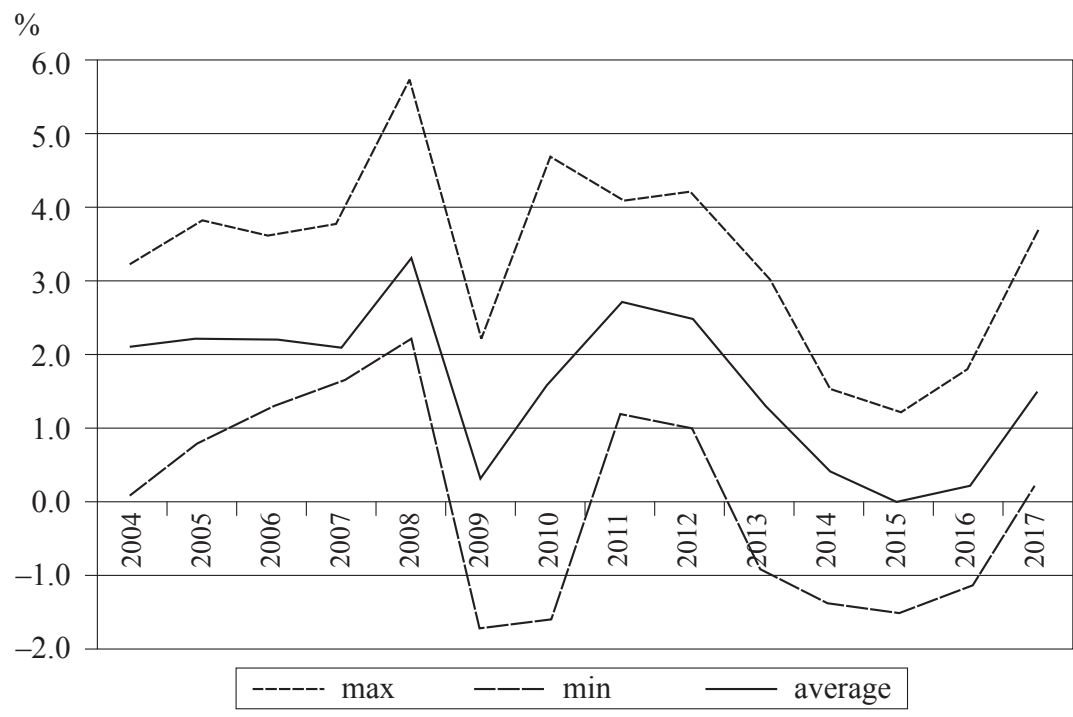

Minimum, maximum and average general price level dynamics in the euro area in 20042017

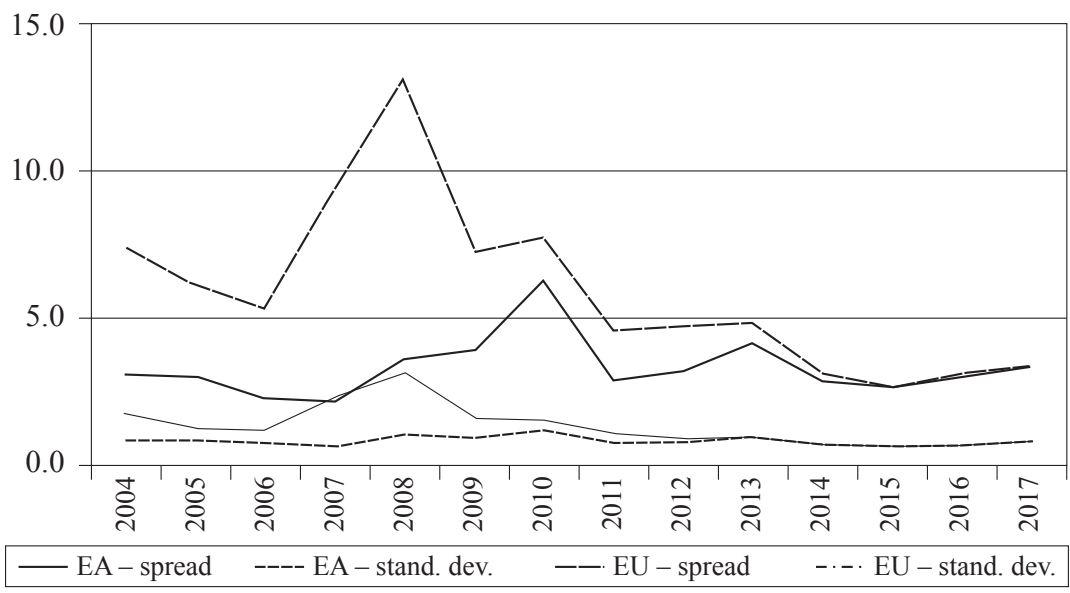

\section{Range and standard deviation of general price level dynamics} in the euro area and the $\mathrm{EU}$ in $\mathbf{2 0 0 4 2 0 1 7}$

Source: Authors' study based on Eurostat data. 


\section{Assessment of Poland's nominal convergence with the euro area in terms of the general price level dynamics}

The aim of the empirical study was to assess Poland's convergence with the euro area in terms of price dynamics, both in terms of short-term compliance to the Maastricht criterion and long-term prospects for conformity to the ECB's unified monetary policy. The analyzed period was set as the years 2004-2017. The starting point marks Poland's accession to the EU and the resulting possibility to apply for accession to the euro area. The closing time point is connected with the availability of data for analysis.

Convergence was assessed taking into consideration both the Maastricht criterion in its original form, and the authors' proposal of a methodology formulated based on the observations presented in the previous chapter of this paper. In this context, several solutions modifying the methodology for this criterion need to be proposed.

- Eliminating from the EU reference group those countries, in which deflation is recorded, and instead considering only countries with zero and/or positive price dynamics, or possibly the adoption of a minimum value of the criterion e.g. at $15 \%$. In this way, a guarantee could be provided for a protection barrier against deflation amounting to $1.5 \mathrm{pp}$. A comparison of such a determined criterion to the methodology failing to exclude countries experiencing deflation is presented in Fig. 2.

- Establishment of the criterion at the level of the ECB inflation target with an admissible fluctuation barrier, e.g. an arbitrary $0.5 \mathrm{pp}$. In this way, we would ensure the stability of the criterion and the constancy of its value for the candidate country, while the target would be symmetrical in character, i.e. it would treat inflation and deflation threats equally, taking into consideration the antideflation barrier of $1.5 \mathrm{pp}$, and additionally it would refer to the value which will be binding in the long-term perspective of EA membership (Fig. 3).

- Establishment of the criterion at the level of average price dynamics in the euro area with the admissible fluctuation barrier, identified, for example, based on the statistics concerning variation in price dynamics within the EA (standard deviation, range, etc., see Fig. 3). The strength of this variant stems from the fact that it refers to the situation in which the current average price dynamics in the euro area deviates from the target value of $2 \%$. In this way, thus established, the criterion would more effectively refer to the current economic situation, 
and it would refer to the EA rather than the entire EU. Additionally, this variant would take into consideration the general price level dynamics as an argument in the discussion on the inflation target value (see formula 1). This methodology may also be supplemented by the minimum upper level for the criterion (e.g. $1.5 \%$ or $2 \%$ - compare the ECB target) (Fig. 3).

Price dynamics in Poland (HICP) in view of such formulated variants of the criteria in the years 2004-2017 are presented in Figs. 2 and 3. In Fig. 2, we can observe considerable differences in the criterion values when comparing the original methodology assuming the incorporation of reference countries experiencing deflation and the values obtained when the above-mentioned countries are excluded from the analysis. The differences are mainly evident in the years 2009-2010, i.e. during the global financial and economic crisis, and 2013-2016, i.e. in the face of downward trends in raw material prices, including oil prices on global markets. In those years, except for 2013, the value of the criterion when deflation was not excluded from analysis was dangerously low, dropping below 1\%. During the 14 investigated years, Poland would have met the criterion 8 times, including the last 5 years, and interestingly, this would be the case irrespective of the potential exclusion of the countries experiencing deflation. In recent years, despite the low value of the criterion, price dynamics in Poland were also very low, and consistent with the global trends in this respect in view of decreasing raw material prices. This convergence was found under the effect of demand factors, whereas during the crisis and the resulting negative demand shock (e.g. in 2009) it was no longer observed. Macroeconomically, in that period, our economy was in relatively good shape ${ }^{6}$ and for this reason it was not subject to deflationary processes. However, if at that time it had been necessary to meet the Maastricht criterion, restrictive monetary (or possibly fiscal) policies would have been required in order to adapt to the 'unnaturally' low criterion value, generating tremendous socio-economic costs as a consequence. Additionally, taking into consideration reference countries experiencing deflation would cause an absurd situation (see Fig. 2 ) in which in some years the ECB itself would not meet the Maastricht criterion (see average price dynamics for the EA). Such a controversial situation clearly shows the flaws of the currently applied methodology for

${ }^{6}$ It is evidenced by studies applying an original method based on a multifactorial economic assessment measure (Błaszczyk, 2015). 
the Maastricht inflation criterion and thus it confirms the advisability of its adjustment.

Thus, we can propose the exclusion of countries experiencing deflation (Fig. 2) from the current methodology, which would result in the minimum value of the criterion being $1.5 \%$, i.e. at a level which in economic central banking practice refers to the lower values considered optimal in relation to price stability (compare the inflation target for Poland). For example, such a methodological approach applied for the middle of the 2009 crisis and under the global deflation trends in 2014-2016 would result in the criterion value being arbitrarily limited and never dropping below $1 \%$, i.e. a value inconsistent with the contemporary definitions of price stability in Europe and worldwide. Additionally, average price dynamics in the EA would take values below the criterion limit.

Fig. 2. Price dynamics in Poland and the EA in the years 2004-2017 in view of the original methodology for the Maastricht criterion and following the exclusion of countries experiencing deflation

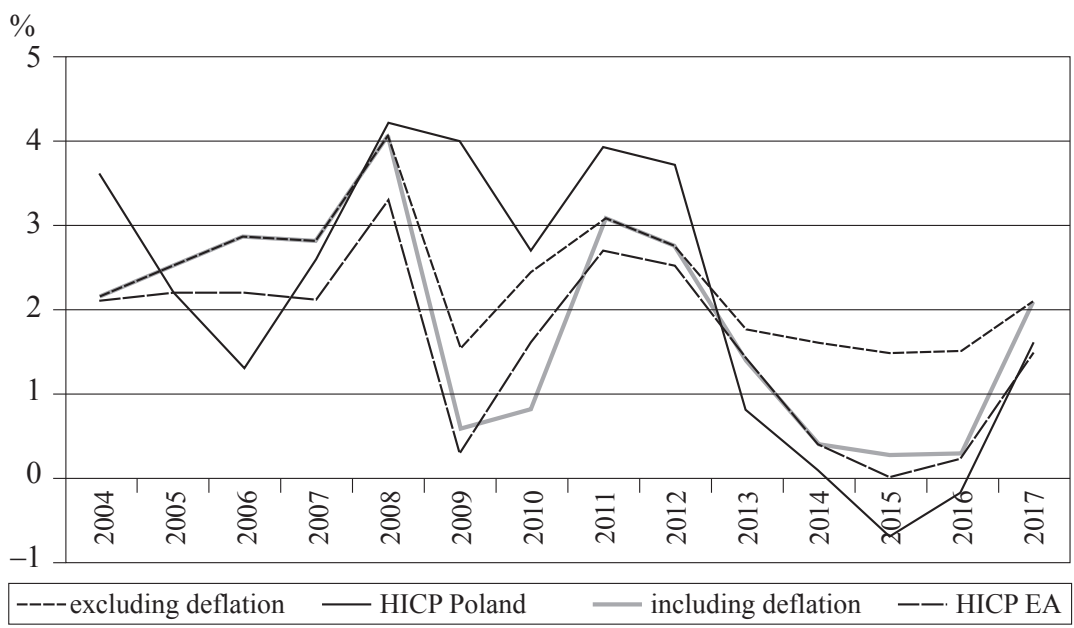

Source: Authors' study based on Eurostat data.

While convergence in price dynamics is crucial in view of overall economic integration in Europe, and at the present stage of compliance with the unified monetary policy of the Monetary Union, a question arises whether it should be verified in relation to EU member states, or rather to countries with the lowest price dynamics. This is a major issue, since 
the candidate country, in order to reduce the costs related to the loss of autonomy in the monetary and exchange rate policies and the resulting potential threat to the unified monetary policy, should adapt in terms of price dynamics to the average trend in the euro area. It is the EA average, rather than the lowest price dynamics in the EU, that is the primary benchmark for actions undertaken by the ECB and an element of the impulse response function. Nevertheless, the former should be taken into consideration within the multiparametric approach, including regional variation in price dynamics (compare below).

For this reason, we need to consider the methodology of the criterion referring to the ECB inflation target with the admissible fluctuation barrier arbitrarily established at, say, $0.5 \%$. In Figure 3, the upper and lower values of such a determined criterion are marked with black and red broken lines (the target plus 0.5 , the target minus 0.5 ). In view of the above, Poland would have serious problems with meeting the accession criterion. The price dynamics is so unstable that it would have fallen within the target range only in 2017, while it would have exceeded it 7 times and been below it 5 times. While the proposed methodology is justified logically and factually, in practice it might prove too harsh for candidate countries (for comparison, see price dynamics for the EA).

Since price dynamics do not always need to comply with the ECB target, e.g. due to global demand or supply trends, including those resulting from raw material prices, the next proposed change in the criterion methodology refers to the average price dynamics in the EA. The criterion would include admissible upward and downward fluctuations by the value of standard deviation, possibly including the minimum value of the criterion for the upper limit at 1.5 or $2 \%$ (which would refer to the ECB target and 'safe' inflation values). This approach to a certain degree would take into consideration regional variations in price dynamics and the H-B-S effect. Such a specified criterion is shown in Fig. 3 as the black (stand. dev. plus) and red (stand. dev. minus) dotted lines. In view of the above, Poland would have met the criterion requirements 8 times, it would have exceeded it 3 times, and Poland would have failed twice to reach the lower limit by a slight margin.

This may be generally considered to be a good result, on the one hand showing the correct choice of criterion methodology, while on the other hand indicating the convergence of price dynamics in Poland with that in the euro area. The first conclusion is difficult to verify defini- 
Fig. 3. Price dynamics in Poland and the EA in the years 2004-2017 in view of proposed changes in the Maastricht criterion methodology

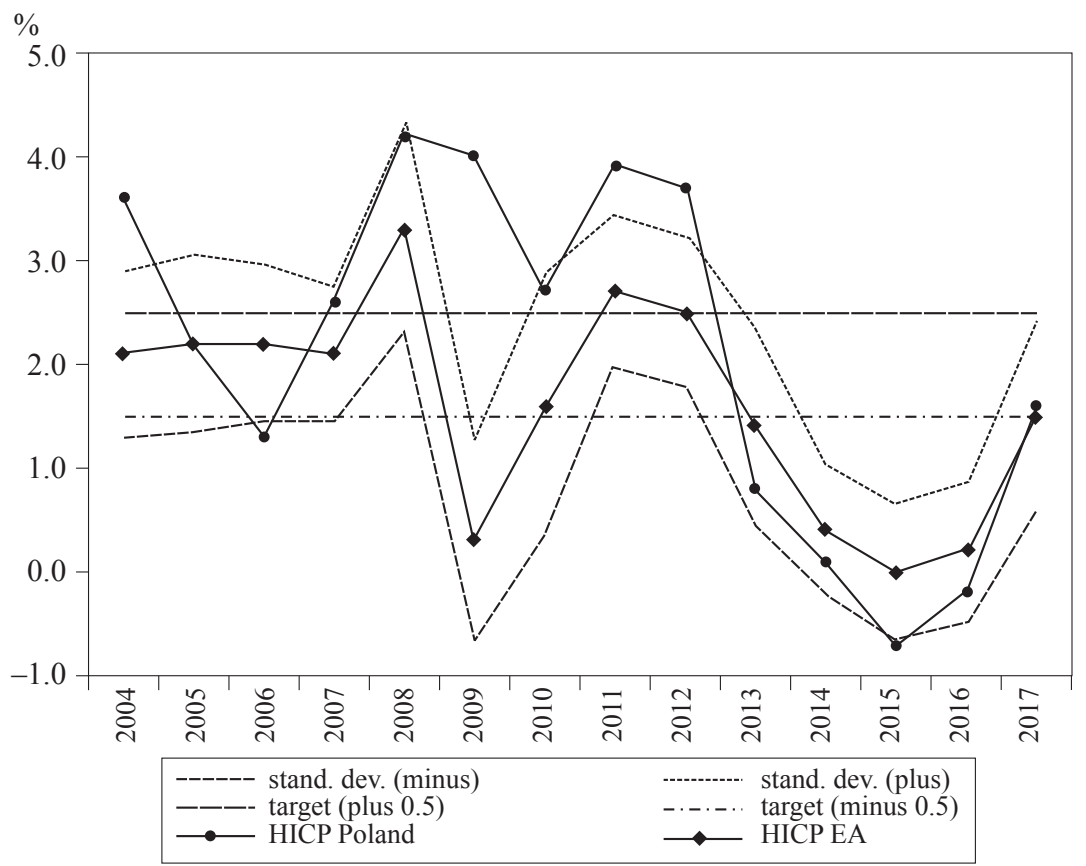

Source: Authors' study based on Eurostat data.

tively. However, further studies need to be conducted on the authors' proposal for optimal inflation, focusing on the uniformity of the monetary policy and price differentiations in the Monetary Union, even if it seems factually sound and compliant with economic practice in terms of price stability.

The second conclusion is doubtful, since price dynamics (see Figs. 2 and 3 ) in Poland for the entire period of analysis differed from that of the EA and were less stable (except for 2017, with $1.6 \%$ and $1.5 \%$, respectively). In certain years, the price dynamic was greater, while in others it was lower. The average for the 2004-2017 period for Poland was higher and amounted to $2.1 \%$, whereas for the EA it was $1.7 \%$. The weak convergence of price dynamics in Poland to that of the EA is presented more comprehensively in Fig. 4 in relation to price levels (and not as previously - the rate of changes in price dynamics). 
Fig. 4. Price levels in Poland and in the EA in the years 2004-2017 with 2005 as the benchmark

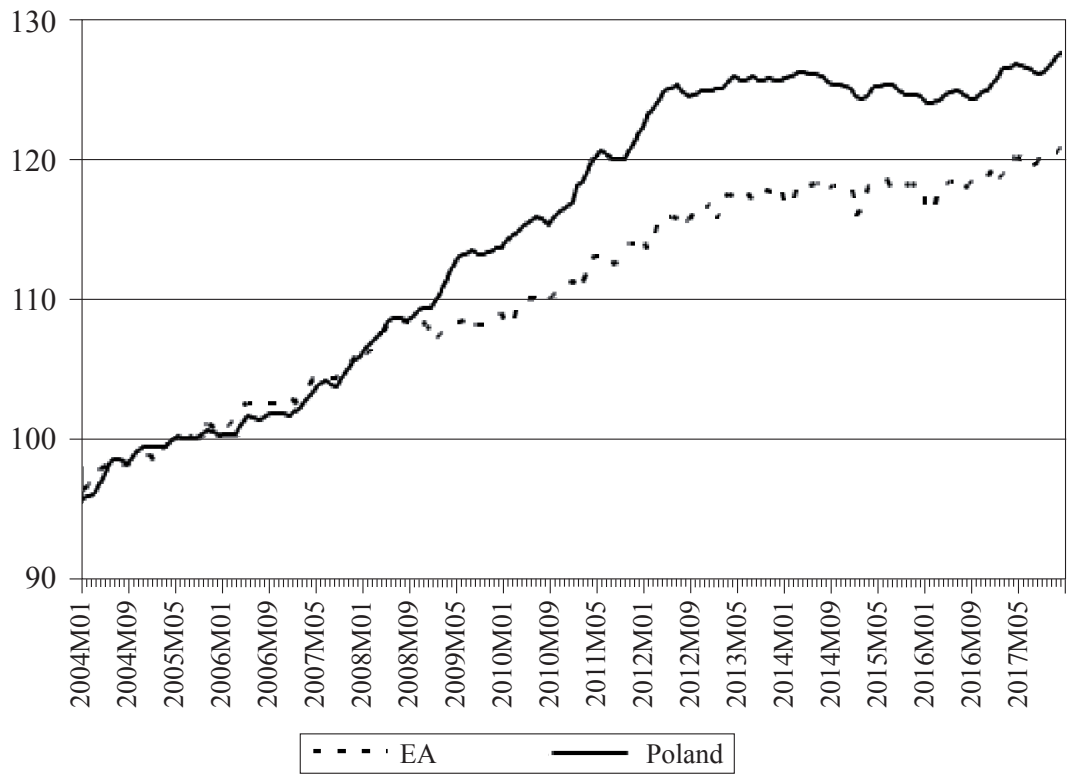

Source: Authors'study based on Eurostat data.

In this approach, considerable convergence was observed in the period until the global financial and economic crisis of the first decade of the $21^{\text {st }}$ century. Next, we can observe an increase in price levels in Poland above the EA level, which is consistent with the fact that in a developing country increased GDP dynamics B is accompanied by price dynamics. The divergence in price levels stopped around 2013. Since then, we can observe a degree of stabilization or even slight progress in convergence for both time series.

\section{Conclusion}

The Polish economy is undergoing a continuous convergence process, as it is developing in the context of European integration, and - particularly - of the possible accession to the euro area. The necessary pre-condition for the adoption of euro is connected with meeting the Maastricht 
criteria. In recent years, we have been witnessing progress in this field, particularly in fiscal aspects. In terms of the monetary sphere analyzed in this paper, particularly the general price level dynamics, in recent years the inflation criterion would also have been met, both in terms of its original methodology and the authors' original proposal to adjust it.

However, this does not mean that the monetary authorities may have no concerns over meeting the inflation criterion in the future, when the political decision on accession to the euro area is finally made. In contrast, due to the relative character of this criterion its value is not certain. In particular, the European and global economic situation, by affecting domestic price dynamics including the reference countries, strongly determines its level. The last decade at the global demand and supply economic shocks and deflation showed that it may be very low, even close to zero. There is no consensus on the identification of reference countries experiencing deflation. As a consequence the criterion value may prove very low, inconsistent with the ECB inflation target, and more broadly with the definition of price stability applied in central banking practice both in Europe and worldwide. Such a situation may irrationally increase the costs associated with accession to the euro area also in the longer time frame.

The methodology for establishing the Maastricht inflation criterion should be modified to take into consideration the threat of excessively low inflation, such as for example downward nominal wage rigidity, the lower nominal interest rate limit as well as regional variation in price dynamics in the Monetary Union. On the one hand, this methodology needs to treat the inflation and deflation threat symmetrically, while on the other hand it should also refer both to the average price dynamics in the euro area and the ECB inflation target. The proposals contained in this paper meet these requirements; nevertheless, further studies need to be conducted, e.g. also including the experiences of countries other than Poland.

It should be taken into account that Poland's accession to the euro area, which has the status of a country with a derogation, is basically a foregone conclusion. The question is not whether we want to enter the Economic and Monetary Union, but when? The decision is mainly conditioned by political will. The current economic situation, in particular with regard to the nominal Maastricht criteria, is beneficial and provides real grounds for their fulfillment in the coming years. Rational decisionmakers, in determining the date of accession, should therefore take into account social and economic factors, including the criterion of price sta- 
bility considered here, and not only purely political premises, including electoral ones.

\section{Bibliography}

Akerlof G. A., Dickens W. T., Perry G. L. (1996), The Macroeconomics of Low Inflation, Brookings Papers on Economic Activity, vol. 1.

Akerlof G. A., Dickens W. T., Perry G. L. (2000), Near-Rational Wage and Price Setting and the Optimal Rates of Inflation and Unemployment, Brooking Papers on Economic Activity, vol. 1.

Aldasoro J. I., Zdarek V. (2009), Inflation Differentials in the Euro Area and their Determinants - an empirical view, William Davidson Institute Working Paper, no. 958 , April.

Błaszczyk P. (2010), Stabilność cen - sposoby definicji oraz konsekwencje dla polityki pieniężnej, Materiały i Studia NBP, no. 249.

Błaszczyk P. (2014), Wybrane problemy definicji stabilności cen $w$ odniesieniu do strefy euro in: Gospodarka w warunkach integracji europejskiej, eds. D. J. Mierzejewski, J. Polcyn, Państwowa Wyższa Szkoła Zawodowa w Pile, Piła, pp. 13-24.

Błaszczyk P. (2015), Post-crisis macroeconomic comparative assessment of the Eurozone member states with the use of an improved misery index, "Journal of Business \& Economic Policy," no. 3.

Błaszczyk P. (2016), Price Level Dynamics Differentiation as a Problem of Definition of Price Stability in the Euro Area, "Business Research Review," vol. 2, no. 1.

Chmielewski T. (2003), Od kursu plynnego do unii monetarnej. Znaczenie efektu Balassy-Samuelsona dla polskiej polityki pieniężnej, "Materiały i Studia NBP," no. 163.

Cukrowski J. (2001), Renta emisyjna jako źródto finansowania budżetu państwa, CASE, Warszawa.

De Grauwe P. (2003), Unia walutowa. Funkcjonowanie $i$ wyzwania, PWE, Warszawa.

Devicienti F. (2004), Downward Nominal Wage Rigidity in Italy: Evidence and Consequences, LABORatorio R. Revelli Working Paper, no. 20.

ECB (2003), Background Studies for the ECB's Evaluation of its Monetary Policy Strategy, https://www.ecb.europa.eu/pub/pdf/other/monetarypolicystrategyreview_backgrounden, 29.07.2018.

Ekberg J. (2002), Nominal Wage Rigidity on the Swedish Labor Market, Mimeo, Stockholm School of Economics.

Fehr E., Goette L. (2000), Robustness and Real Consequences of Nominal Wage Rigidity, "Journal of Monetary Economics," vol. 52 no. 2005. 
Friedman B. L. (red.), Solow R. M., Taylor J. B. (2002), Inflacja, bezrobocie a polityka monetarna, CeDeWu, Warszawa.

IMF, International Monetary Fund (1999), Safeguarding Macroeconomic Stability at Low Inflation, World Economic Outlook, October.

Keynes J. M. (2003), Ogólna teoria zatrudnienia, procentu i pieniadza, PWN, Warszawa.

Kilian L., Manganelli S. (2007), Quantifying the Risk of Deflation, "Journal of Money, Credit and Banking," vol. 39, nos. 2-3.

Kimura T., Ueda K. (1997), Downward Nominal Wage Rigidity in Japan: Is Price Stability Costly?, Bank of Japan Working Paper.

Knoppik C., Beissinger T. (2001), How Rigid are Nominal Wages? Evidence and Implications for Germany, "Scandinavian Journal of Monetary Economics," no. 105.

Kumar M. S., Baig T., Decressin J., Faulkner-MacDonagh C., Feyzioglu T. (2003), Deflation. Determinants, Risks, and Policy Options, International Monetary Fund, Occasional Paper, no. 221.

Kwiatkowski E. (2002), Bezrobocie. Podstawy teoretyczne, PWN, Warszawa.

Lebow D. E., Saks R. E., Wilson B. A. (2003), Downward Nominal Wage Rigidity. Evidence from the Employment Cost Index, "Advances in Macroeconomics," vol. 3 .

Molle W. (2000), Ekonomika integracji europejskiej. Teoria, praktyka, polityka, Fundacja Gospodarcza, Gdańsk.

Moretti L. (2014), Determinants of inflation differentials in the euro area, CFS Working Paper Series, no. 451, Center for Financial Studies.

NBP (2009), Raport na temat petnego uczestnictwa Rzeczypospolitej Polskiej w trzecim etapie Unii Gospodarczej i Walutowej, Warszawa.

Nickell S. J., Quintini G. (2003), Nominal Wage Rigidity and the Rate of Inflation, "Mimeo. The Economic Journal," no. 113.

Ochryniuk M., Rogut A. (2010), Konwergencja nominalna w strefie euro. Implikacje dla Polski, NBP, https://www.nbp.pl/publikacje/o_euro/konwergencja_nominalna.pdf. 30.07.2018.

Pronobis M. (2008), Polska w strefie euro, C.H. Beck, Warszawa.

Social Security Administration (1996), The Boskin Commission Report, Toward a More Accurate Measure of the Cost of Living, https://www.ssa.gov/history/ reports/boskinrpt.html (30.01.2018)

Svensson L. E. O. (2000), How should monetary policy be conducted in an area of price stability?, NBER Working Paper, no. 7516.

Szeląg K. (1998), Wprowadzenie euro - geneza, kluczowe decyzje, aspekty prawne, „Bank i Kredyt," no. 10.

Walkowski M. (2012), Unia Europejska - rozpad czy powrót do równowagi makroekonomicznej i finansowej? Rozważania na temat kryzysu w strefie euro z perspektywy europejskiej i światowej, „Środkowoeuropejskie Studia Polityczne,” no. 3 . 
Weber A. A., Beck G. W. (2005), Price Stability, Inflation Convergence and Diversity in EMU: Does One Size Fit All?, Center for Financial Studies, no. 2005/30.

Wojtyna A. (2001), Skuteczność polityki pieniężnej $w$ warunkach niskiej inflacji: problem zerowej granicy nominalnych stóp procentowych, „Bank i Kredyt,” no. 7.

Wojtyna A. (2004), Szkice o polityce pieniężnej, PWE, Warszawa.

Wójcik C. (2008), Integracja ze strefa euro. Teoretyczne i praktyczne aspekty konwergencji, PWN, Warszawa.

Wynne M., Rodriguez-Palenzuela D. (2002), Measurement Bias in the HICP: What Do We Know and What Do We Need to Know?, Federal Reserve Bank of Dallas Working Paper, no. 206.

Zombirt J. (2008), Mechanizmy rynku wewnętrznego Unii Europejskiej, Difin, Warszawa.

Zwierzchlewski S. (2015), Stabilność unii walutowej, Wydawnictwo A. Marszałek, Toruń.

\section{Ocena konwergencji dynamiki cen w perspektywie akcesji Polski do strefy euro ze szczególnym uwzględnieniem deflacji}

\section{Streszczenie}

Podstawowym celem opracowania jest ocena stopnia konwergencji Polski w zakresie stabilności cen, zarówno na etapie kandydowania do strefy euro i w odniesieniu do kryteriów z Maastricht, jak i w szerszym ujęciu w kontekście jednolitej polityki pieniężnej EBC. Zakres czasowy badania obejmuje okres 2004-2017. Dolna cezura czasowa wynika z przystąpienia Polski do UE, co warunkuje możliwość ubiegania się o przynależność do strefy euro. Górna cezura czasowa wynika z dostępności danych, głównie w odniesieniu do Eurostat. Realizacja celu została dokonana na tle analizy krytycznej metodyki i sposobu wyznaczania kryterium z Maastricht dotyczącego dynamiki ogólnego poziomu cen. Metodyka wyznaczania kryterium inflacyjnego jest wadliwa i niedopasowana do współczesnych uwarunkowań gospodarczych, w tym na tle definicji stabilności cen stosowanych w praktyce bankowości centralnej, a także w kontekście zjawiska deflacji powszechnie występującego w ostatniej dekadzie. W konsekwencji wartość kryterium dla kraju kandydującego może okazać się bardzo niska i może w nieuzasadniony sposób zwiększać koszty akcesji do strefy euro, również w długim horyzoncie czasowym. Taki problem powinien być uwzględniany w dyskusji na temat akcesji Polski do strefy euro, która przeważnie ma charakter polityczny i dalej społeczny oraz ekonomiczny. To aspekt ekonomiczny jednak powinien być w praktyce kluczowy.

Słowa kluczowe: deflacja, integracja gospodarcza, strefa euro, polityka pieniężna, stabilność cen 